\title{
ANALISIS KEBUTUHAN SARANA DAN PRASARANA PEMUKIMAN PADA KECAMATAN MUNGKAJANG KOTA PALOPO
}

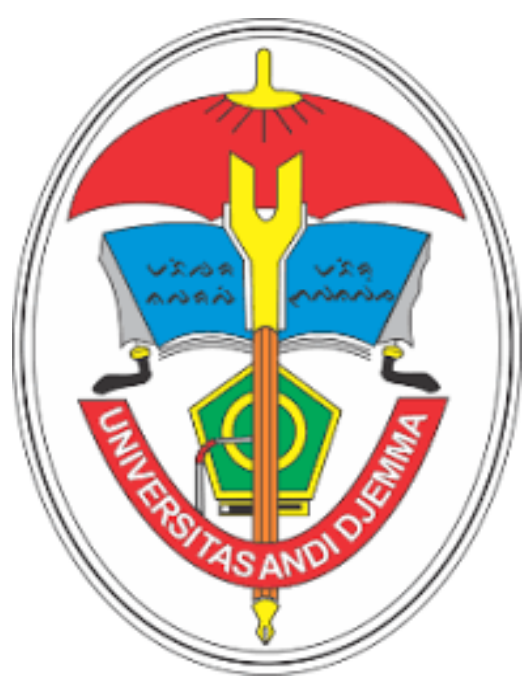

OLEH :

GITA SASMITA 17.023.22.201.177

RIFALDI SUROSO 17.023.22.201.

ARDIANSYAH MANNAUGAN 18.023.22.201.113

MUHAMMAD ALDI 18.023.22.201.144

DOSEN :

AMIRUDDIN AKBAR FISU, ST., MT.

UNIVERSITAS ANDI DJEMMA

FAKULTAS TEKNIK SIPIL

2021/2022 


\section{KATA PENGANTAR}

Puji syukur kehadirat Allah Swt. atas segala limpahan Rahmat, Inayah, Taufik dan Hinayahnya sehingga saya dapat menyelesaikan penyusunan makalah ini dalam bentuk maupun isinya yang sangat sederhana. Semoga makalah ini dapat dipergunakan sebagai salah satu acuan, petunjuk maupun pedoman bagi pembaca.

Harapan saya semoga makalah ini membantu menambah pengetahuan dan pengalaman bagi para pembaca, sehingga saya dapat memperbaiki bentuk maupun isi makalah ini sehingga kedepannya dapat lebih baik.

Makalah ini saya akui masih banyak kekurangan karena pengalaman yang saya miliki sangat kurang. Oleh kerena itu saya harapkan kepada para pembaca untuk memberikan masukan-masukan yang bersifat membangun untuk kesempurnaan makalah ini.

Palopo, 15 januari 2022

Penulis 


\begin{abstract}
ABSTRAK
Kecamatan Mungkajang adalah salah satu kecamatan dari 9 kecamatan yang berada di wilayah Kota Palopo. Secara geografis, kecamatan mungkajang berada di seblah Barat wilayah Kota Palopo berbatasan dengan kecematan Wara Barat di seblah Utara, di seblah selatan berbatas dengan kecamatan Wara dan kecamatan sendana , kabupaten Luwu dan kabupaten Toraja Utara di seblah Barat dan Kecamatan Wara di seblah Timur.

Dengan Wilayah $\pm 53,80 \mathrm{~km}^{2}$, luas wilayah tersebut merupakan 21,74 persen dari total luas wilayah Kota Palopo.

Secara Astronomis Kecamatan Mungkajang terletak pada $3^{0} 1$ '18', LS dan $12^{0} 10^{\prime} 37^{\prime}$ 'BT.

Wilayah terluas di kecamatan Mungkajang berada pada kelurahan Latuppa dengan Luas 18,33 $\mathrm{km}^{2}$ atau 34,07 \% dari total luas Kecamatan Mungkajang. Ibu Kota Kecamatan Mungkajang adalah Kelurahan Mungkajang, jarak terdekat dari kelurahan ini yaitu Kelurahan Murante dengan Jarak sejauh 2 km sedangkan jarak terjauh yaitu kelurahan kambo sejauh $10 \mathrm{~km}$.
\end{abstract}




\section{BAB I \\ PENDAHULUAN}

A. Latar Belakang

Kecamatan Mungkajang adalah salah satu kecamatan dari 9 yang berada di wilayah Kota Palopo, yangdi bentuk berdasarkanPeraturan Daerah Kota Palopo Nomor 03 Tahun 2005.

Secara geografis, Kecamatan Mungkajang berada di sebla wilayah Kota Palopo. Berbatasan dengan kecamatan Wara Barat disebla utara, di seblah Selatan berbatasan dengan KecamatanWara dan kecamatan Sendana, Kabupaten Luwu dan Kabupaten Toraja Utara di sebblah Barat dan Kecamatan di seblah Timur .

Dengan luas wilayah $\pm 53,80 \mathrm{~km}^{2}$, luas wilayah tersebut merupakan 21,74 persen dari total luas wilayah Kota Palopo. Secara Astronomis Kecamatan Mungkajang terletak pada $31^{\circ} 1^{\prime} 18^{\prime \prime}$ LS dan $12^{\circ} 10^{\prime} 37^{\prime \prime B T}$.

Wilayah terluas di Kecamatan Mungkajang berada pada Keluurahan Latuppa dengan Luas 18,33 $\mathrm{km}^{2}$ atau 34,07 persen dari total luas Kecamatan Mungkajang . Ibu Kota Kecamatan Mungkajang adalah Kelurahan mungkajang. Jarak terdekat dari kelurahan ini yaitu Kelurahan Murante dengan jarak sejauh 2 km sedangkan jarak terjauh yaitu Kelurahan Kambo sejauh 10 km.

Jarak yang ditempuh dari Kelurahan Mungajang ke ibu Kota Palopo adalah sejauh 3 km. selama Kurun waktu tahun 2013-2015 tidak ada perubahan jumlah wilayah administrasi akibat pemekaran wilayah di Kecamatan Mungkajang pada tingkat kelurahan.

B. Tujuan

Tujuan permasalahan dari Statik Daerah Kecamatan Mungkajang 5 Tahun Terahkir

Mengkaji permasalahan tentang fasilitas pendidikan, ekonomi, dan kesehatan lalu proyeksi penduduk 20 tahun yang akan dating. 


\section{BAB II \\ LANDASAN TEORI}

C. Prasarana Wilayah Dan Standar Prasarana Wilayah

Berdasarkan Sensus Penduduk 2010, Penduduk Kecamatan Mungkajang mencapai 7,140 jiwa dan pada tahun 2015 terjadi penigkatan dimana jumlah penduduk Kecamatanmungkajang adalah7,575 jiwa yang terdiri dari 3,702 lakilaki dan 3,873 perempuan. Dengan Luas wilayah sekitar 53,80 $\mathrm{km}^{2}$. Dengan kepadatan setiap $\mathrm{km}^{2}$ di tempati penduduk 141 orang.

Secara umum jumlah penduduk perempuan lebih banyak di bandingkan dengan jumlah penduduk laki-laki. Stuktur umum penduduk saat ini merupakan hasil kelakirah, kematian dan migrasi masa lalu dan menentukan perkembangan penduduk di masa yang akan datang .

Ketersedian sarana dan prasarana kesehatan sebagai salah satu factor penunjang terpenuhinya salah satu kebutuhan kebutuhan mendasa manusia yaitu kesehatan , mutlak sangatdi butukan. Hingga tahun 2015 di Kecamatan Mungkajang dan pendidikan salah satu modal utama pendukung kemajuan suatu bangsa. Ini tentunya tidak terlepas dari sarana dan prasarana yang memadai, Sarana dan prasarana pendidikan yang baik tentunya dapat di perlancar proses pendidikan untuk menghasilkan output pendidikan yang baik pula. Sampai tahun 2015, di Kecamatan Mungkajang sudah terdapat fasilitas pendidikan. 


\section{Sarana Pendidikan Dan Pembelajaran}

Dasar penyediaan sarana pendidikan adalah untuk melayani setiap unit administrasipemerintahan baik yang informal (RT, RW) maupun yang formal (Kelurahan, Kecamatan),dan bukan didasarkan semata-mata pada jumlah penduduk yang akan dilayani oleh saranatersebut. Dasar penyediaan sarana pendidikan ini juga mempertimbangkan pendekatan desain keruangan unit-unit atau kelompok lingkungan yang ada. Tentunya hal ini dapat terkaitdengan bentukan grup bangunan/blok yang nantinya terbentuk sesuai konteks lingkungannya. Sedangkan penempatan penyediaan fas ilitas ini akan mempertimbangkan jangkauan radius area layanan terkait dengan kebutuhan dasar sarana yang harus dipenuhi untuk melayani pada area tertentu. Perencanaan sarana pendidikan harus didasarkan pada tujuan pendidikan yang akandicapai, dimana sarana pendidikan dan pembelajaran ini akan menyediakan ruang belajar harus memungkinkan siswa untuk dapat mengembangkan pengetahuan, keterampilan, serta sikap secara optimal.

Oleh karena itu dalam merencanakan sarana pendidikan harus memperhatikan:

a) berapa jumlah anak yang memerlukan fasilitas ini pada area perencanaan

b)optimasi daya tampung dengan satu shift;

c) effisiensi dan efektifitas kemungkinan pemakaian ruang belajar secara terpadu;

d) pemakaian sarana dan prasarana pendukung;

e) keserasian dan keselarasan dengan konteks setempat terutama dengan berbagai jenissarana lingkungan lainnya.

Jenis sarana

Sarana pendidikan yang diuraikan dalam standar ini hanya menyangkut bidang pendidikan yang bersifat formal / umum, yaitu meliputi ti ngkat prabelajar (Taman Kanak-kanak); tingkatdasar (SD/MI); tingkat menengah (SLTP/MTs dan SMU). Adapun penggolongan jenis sarana pendidikan dan pembelajaran ini meliputi: a) taman kanak-kanak (TK), yang merupakan penyelenggaraan kegiatan belajar danmengajar pada tingkatan pra belajar dengan lebih menekankan pada kegiatan bermain, yaitu $75 \%$, selebihnya bersifat pengenalan;

b) sekolah dasar (SD), yang merupakan bentuk satuan pendidikan dasar yang menyelenggarakan program enam tahun;

c) sekolah lanjutan tingkat pertama (SLTP), yang merupakan bentuk satuan pendidikandasar yang menyelenggarakan proram tiga tahun sesudah sekolah dasar (SD);

d) sekolah menengah umum (SMU), y ang merupakan satuan pendidikan yang menyelenggarakan program pendidikan menengah mengutamakan perluasan 
pengetahuan dan peningkatan keterampilan siswa untuk melanjutkan pendidikan kejenjang pendidikan tinggi;

e) sarana pembelajaran lain yang dapat berupa taman bacaan ataupun perpustakaan

umum lingkungan, yang dibutuhkan di suatu lingkungan perumahan sebagai sarana untuk meningkatkan minat membaca, menambah ilmu pengetahuan, rekreasi serta sarana penunjang pendidikan.

Kebutuhan ruang dan lahan Berbagai pertimbangan yang harus diperhatikan pada penentuan kebutuhan ruang dan lahan adalah:

a) Penyediaan jumlah sarana pendidikan dan pembelajaran yang harus disediakan didasarkan pada Tabel 9.

b) Kebutuhan sarana pendidikan prabelajar serta pendidikan tingkat dasar dan menengah, harus direncanakan berdasarkan perhitungan proyeksi jumlah siswa dengan cara sebagaimana Rumus 2, Rumus 3, Rumus 4 dan Rumus 5, yang akan menentukan tipe sekolah serta kebutuhan jumlah ruang, luas ruang dan luas lahan. Rumus 2, Rumus 3, Rumus 4 dan Rumus 5, dipergunakan juga untuk menghitung penambahan ruang-ruang belajar pada sekolah-sekolah yang sudah ada.

c) Perencanaan kebutuhan ruang dan lahan untuk sarana pendidikan didasarkan tipemasing-masing sekolah yang dibedakan menurut:

1) jumlah rombongan belajar;

2) jumlah peserta didik;

3) jumlah tenaga kependidikan; kepala sekolah, wakil kepala sekolah, guru, dan tenaga tata usaha;

4) kebutuhan ruang belajar, ruang kantor, dan ruang penunjang;

5) luas tanah, dan lingkungan/lokasi sekolah.

d) Kebutuhan luas lantai dan lahan untuk masing-masing sarana pendidikan tergantung pada tipe sekolah untuk masing-masing tingkatan pendidikan. Untuk perencanaan bangunan SMU, mengacu pada SNI-03-1730-2002 tentang Tata cara perencanaan bangunan gedung sekolah menengah umum. Dasar penyediaan ini juga akan mempertimbangkan pendekatan desain keruangan unit-unit atau kelompok lingkungan yang ada beserta posisi pusat lingkungan yang ada. Tentunya hal ini dapat terkait dengan bentukan grup bangunan / blok yang nantinya lahir sesuai konteks lingkungannya 
Tabel 7 Kebutuhan program ruang minimum

\begin{tabular}{|c|c|c|}
\hline No. & Jenis Sarana & Program Ruang \\
\hline 1. & $\begin{array}{l}\text { Taman Kanak- } \\
\text { kanak }\end{array}$ & $\begin{array}{l}\text { Memiliki minimum } 2 \text { ruang kelas @ } 25-30 \\
\text { murid. Dilengkapi dengan ruang-ruang lain } \\
\text { dan ruang terbuka/bermain } \pm 700 \mathrm{~m}^{2}\end{array}$ \\
\hline 2. & Sekolah Dasar & \multirow{3}{*}{$\begin{array}{l}\text { Memiliki minimum } 6 \text { ruang kelas @ } 40 \text { murid } \\
\text { Dilengkapi dengan ruang-ruang lain dan } \\
\text { ruang terbuka / bermain } \pm 3000-7000 \mathrm{~m}^{2}\end{array}$} \\
\hline 3. & SLTP & \\
\hline 4. & SMU & \\
\hline 5. & Taman Bacaan & Memiliki minimum 1 ruang baca @ 15 murid \\
\hline
\end{tabular}

CATATAN Acuan diambil dari SNI 03-1733-1989, Tata cara perencanaan kawasan perumahan kota

Tabel 8 Kebutuhan sarana pendidikan dan pembelajaran

\begin{tabular}{|c|c|c|c|c|c|c|c|c|}
\hline \multirow[b]{2}{*}{ No. } & \multirow[b]{2}{*}{$\begin{array}{l}\text { Jenis } \\
\text { Sarana }\end{array}$} & \multirow{2}{*}{$\begin{array}{c}\text { Jumlah } \\
\text { Penduduk } \\
\text { pendukung } \\
\text { (jiwa) }\end{array}$} & \multicolumn{2}{|c|}{$\begin{array}{l}\text { Kebutuhan Per } \\
\text { Satuan Sarana }\end{array}$} & \multirow[b]{2}{*}{$\begin{array}{l}\text { Standard } \\
\left(\mathrm{m}^{2} / \mathrm{jiwa}\right)\end{array}$} & \multicolumn{2}{|c|}{ Kriteria } & \multirow[b]{2}{*}{ Keterangan } \\
\hline & & & $\begin{array}{l}\text { Luas } \\
\text { Lantai } \\
\text { Min. } \\
\left(\mathbf{m}^{2}\right)\end{array}$ & $\begin{array}{l}\text { Luas } \\
\text { Lahan } \\
\text { Min. } \\
\left(\mathbf{m}^{2}\right)\end{array}$ & & $\begin{array}{c}\text { Radius } \\
\text { pencapaian }\end{array}$ & $\begin{array}{l}\text { Lokasi dan } \\
\text { Penyelesaian }\end{array}$ & \\
\hline 1. & $\begin{array}{l}\text { Taman } \\
\text { Kanak- } \\
\text { kanak }\end{array}$ & 1.250 & $\begin{array}{r}216 \\
\text { termasuk } \\
\text { rumah } \\
\text { penjaga } \\
36 \mathrm{~m} 2\end{array}$ & 500 & $0,28 \mathrm{~m} 2 / \mathrm{j}$ & $500 \mathrm{~m}^{\prime}$ & \multirow{2}{*}{$\begin{array}{l}\text { Di tengah } \\
\text { kelompok warga. } \\
\text { Tidak } \\
\text { menyeberang } \\
\text { jalan raya. } \\
\text { Bergabung } \\
\text { dengan taman } \\
\text { sehingga terjadi } \\
\text { pengelompokan } \\
\text { kegiatan. }\end{array}$} & $\begin{array}{l}2 \text { rombongan } \\
\text { prabelajar @ } 60 \\
\text { murid dapat } \\
\text { bersatu dengan } \\
\text { sarana lain }\end{array}$ \\
\hline 2. & $\begin{array}{l}\text { Sekolah } \\
\text { Dasar }\end{array}$ & 1.600 & 633 & 2.000 & 1,25 & $1.000 \mathrm{~m}^{\prime}$ & & \multirow{4}{*}{$\begin{array}{l}\text { Kebutuhan harus } \\
\text { berdasarkan } \\
\text { perhitungan } \\
\text { dengan rumus 2, } \\
3 \text { dan } 4 \text {. } \\
\text { Dapat digabung } \\
\text { dengan sarana } \\
\text { pendidikan lain, } \\
\text { mis. SD, SMP, } \\
\text { SMA dalam satu } \\
\text { komplek }\end{array}$} \\
\hline 3. & SLTP & 4.800 & 2.282 & 9.000 & 1,88 & $1.000 \mathrm{~m}^{\prime}$ & \multirow{2}{*}{$\begin{array}{l}\text { Dapat dijangkau } \\
\text { dengan } \\
\text { kendaraan umum. } \\
\text { Disatukan dengan } \\
\text { lapangan olah } \\
\text { raga. } \\
\text { Tidak selalu harus } \\
\text { di pusat } \\
\text { lingkungan. }\end{array}$} & \\
\hline 4. & SMU & 4.800 & 3.835 & 12.500 & 2,6 & $3.000 \mathrm{~m}^{\prime}$ & & \\
\hline 5. & $\begin{array}{l}\text { Taman } \\
\text { Bacaan }\end{array}$ & 2.500 & 72 & 150 & 0,09 & $1.000 \mathrm{~m}^{\prime}$ & $\begin{array}{l}\text { Di tengah } \\
\text { kelompok warga } \\
\text { tidak menyebe- } \\
\text { rang jalan } \\
\text { lingkungan. }\end{array}$ & \\
\hline
\end{tabular}

CATATAN Acuan diambil dari SNI 03-1733-1989, Tata cara perencanaan kawasan perumahan kota 
Tabel 9 Pembakuan tipe SD/MI, SLTP/MTs dan SMU

\begin{tabular}{|c|c|c|c|c|}
\hline $\begin{array}{c}\text { Tingkat } \\
\text { Pendidikan }\end{array}$ & $\begin{array}{c}\text { Tipe } \\
\text { Sekolah }\end{array}$ & $\begin{array}{c}\text { Rombongan } \\
\text { Belajar }\end{array}$ & $\begin{array}{c}\text { Peserta Didik } \\
\text { (siswa) }\end{array}$ & Lokasi \\
\hline \multirow{3}{*}{ SD/MI } & Tipe A & 12 & 480 & \\
& Tipe B & 9 & 360 & \\
\hline \multirow{3}{*}{ SLTP/MTs } & Tipe C & 6 & 240 & Dekat dengan \\
& Tipe A & 27 & 1.080 & lokasi ruang \\
& Tipe B & 18 & 720 & terbuka \\
& Tipe C & 9 & 360 & lingkungan \\
SMU & Tipe A & 27 & 1.080 & \\
& Tipe B & 18 & 720 & \\
& Tipe C & 9 & 360 & \\
\hline
\end{tabular}

CATATAN Acuan diambil dari SNI 03-0733-1989, Tata cara perencanaan kawasan perumahan kota

Tabel 10 Kebutuhan ruang belajar pada SD/MI, SLTP/MTs dan SMU

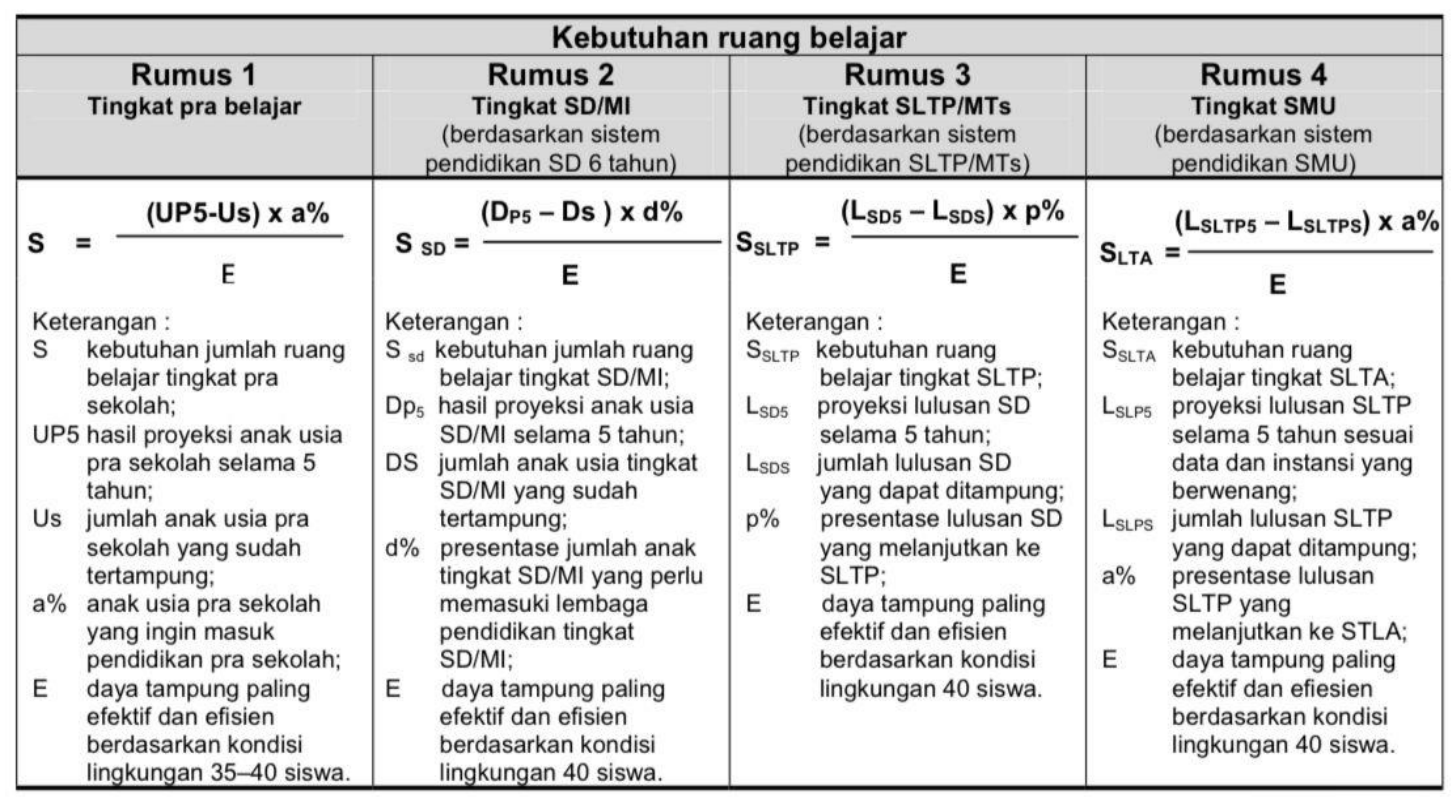

CATATAN Acuan diambil dari SNI 03-1733-1989, Tata cara perencanaan kawasan perumahan kota. 
Tabel 11 Kebutuhan luas lantai dan lahan sarana pendidikan menurut tipe sekolah

\begin{tabular}{|c|c|c|c|c|c|}
\hline $\begin{array}{l}\text { Tingkat } \\
\text { Pendidikan }\end{array}$ & $\begin{array}{c}\text { Tipe } \\
\text { Sekolah }\end{array}$ & $\begin{array}{c}\text { Rombongan } \\
\text { Belajar } \\
\text { (rombongan) }\end{array}$ & $\begin{array}{l}\text { Peserta } \\
\text { Didik } \\
\text { (siswa) }\end{array}$ & $\begin{array}{l}\text { Luas Ruang } \\
\text { Minimum } \\
\left(\mathrm{m}^{2}\right)\end{array}$ & $\begin{array}{c}\text { Luas Lahan } \\
\text { Minimum } \\
\left(\mathrm{m}^{2}\right)\end{array}$ \\
\hline \multirow{3}{*}{ SD/MI } & Tipe A & 12 & 480 & 1.000 & 3.000 \\
\hline & Tipe B & 9 & 360 & 633 & 2.000 \\
\hline & Tipe C & 6 & 240 & 251 & 1.000 \\
\hline \multirow{3}{*}{ SLTP/MTS } & Tipe A & 27 & 1.080 & 3.077 & 9.000 \\
\hline & Tipe B & 18 & 720 & 2.282 & 9.000 \\
\hline & Tipe C & 9 & 360 & 1.502 & 6.000 \\
\hline \multirow{7}{*}{ SMU } & \multirow{3}{*}{ Tipe A } & \multirow{3}{*}{27} & \multirow{3}{*}{1.080} & \multirow{3}{*}{5.233} & 1 lantai: 15.000 \\
\hline & & & & & 2 lantai: 9.500 \\
\hline & & & & & 3 lantai: 7.000 \\
\hline & \multirow{3}{*}{ Tipe B } & \multirow{3}{*}{18} & \multirow{3}{*}{720} & \multirow{3}{*}{3.835} & 1 lantai: 12.500 \\
\hline & & & & & 2 lantai: 8.000 \\
\hline & & & & & 3 lantai: 5.000 \\
\hline & Tipe C & 9 & 360 & 2.692 & 10.000 \\
\hline
\end{tabular}

CATATAN Acuan diambil dari SNI 03-1733-1989, Tata cara perencanaan kawasan perumahan kota.

E. Sarana Kesehatan

Sarana kesehatan berfungsi memberikan pelayanan kesehatan kesehatan kepada masyarakat, memiliki peran yang sangat strate gis dalam mempercepat peningkatan derajat kesehatan masyarakat sekaligus untuk mengendalikan pertumbuhan penduduk. Dasar penyediaan sarana ini adalah didasarkan jumlah penduduk yang dilayani oleh sarana tersebut. Dasar penyediaan ini juga akan mempertimbangkan pendekatan desain keruangan unit-unit atau kelompok lingkungan yang ada. Tentunya hal ini dapat terkait dengan bentukan grup bangunan/blok yang nantinya terbentuk sesuai konteks lingkungannya. Sedangkan penempatan penyediaan fasilitas ini akan mempertimbangkan jangkauan radius area layanan terkait dengan kebutuhan dasar sarana yang harus dipenuhi untuk melayani pada area tertentu.

\section{Jenis sarana}

Beberapa jenis sarana yang dibutuhkan adalah

a) posyandu yang berfungsi memberikan pelayanan kesehatan untuk anak anak usiabalita;

b) balai pengobatan warga yang berfungsi memberikan pelayanan kepada pendudukdalam bidang kesehatan dengan titik berat terletak pada 
penyembuhan ( currative) tanpa perawatan, berobat dan pada waktu-waktu tertentu juga untuk vaksinasi;

c) balai kesejahteraan ibu dan anak (BKIA) / Klinik Bersalin), yang berfungsi melayani ibu baik sebelum, pada saat dan sesudah melahirkan serta melayani anak usia sampai dengan 6 tahun;

d) puskesmas dan balai pengobatan, y ang berfungsi sebagai sarana pelayanan kesehatan tingkat pertama yang memberikan pelayanan kepada penduduk dalam penyembuhan penyakit, selain melaksanakan program pemeliharaan kesehatan dan pencegahan penyakit di wilayah kerjanya; e) puskesmas pembantu dan balai pengobatan, yang berfungsi sebagai unit pelayanan kesehatan sederhana yang memberikan pelayanan kesehatan terbatas dan membantu pelaksanaan kegiatan puskesmas dalam lingkup wilayah yang lebih kecil;

f) tempat praktek dokter, merupakan salah satu sarana yang memberikan pelayanan kesehatan secara individual dan lebih dititikberatkan pada usaha penyembuhan tanpa perawatan; dan

g) apotik, berfungsi untuk melayani penduduk dalam pengadaan obat obatan, baik untuk penyembuhan maupun pencegahan 
Tabel 12 Kebutuhan sarana kesehatan

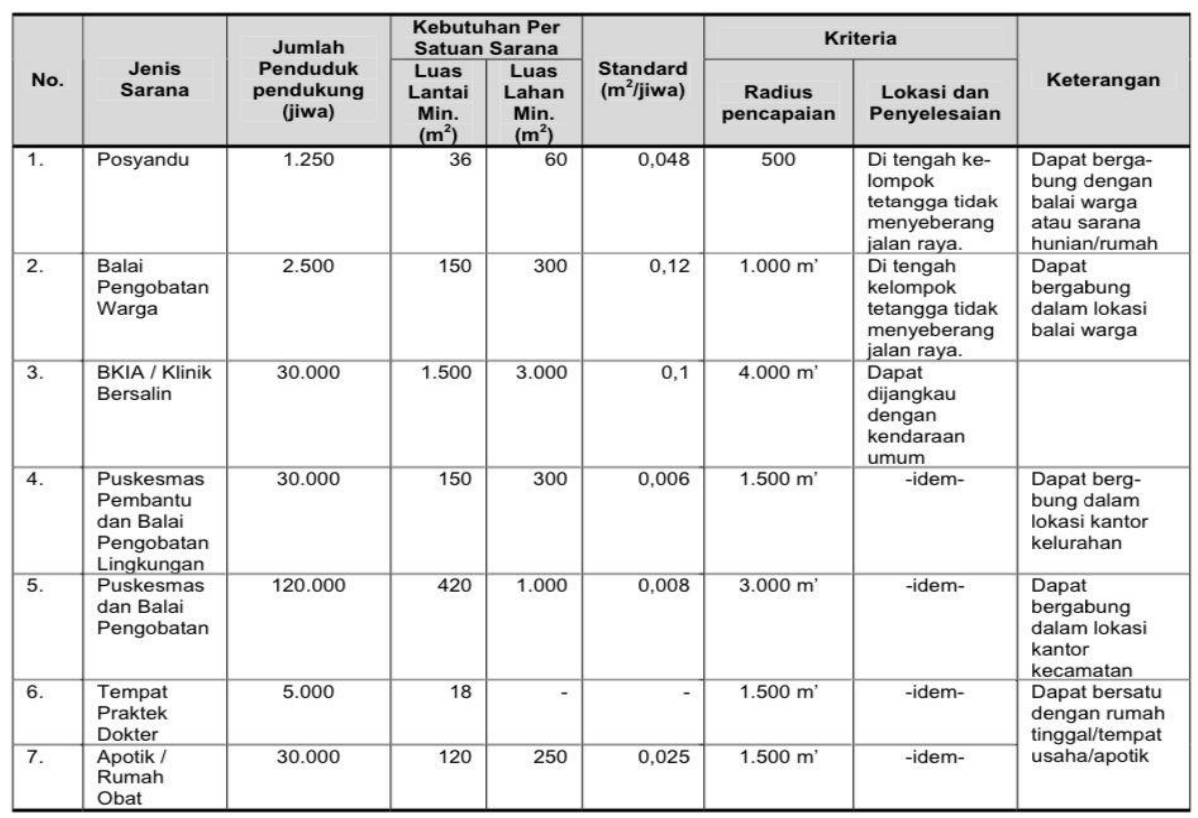

CATATAN Acuan diambil dari SNI 03-1733-1989, Tata cara perencanaan kawasan perumahan kota.

\section{F. Sarana Peribadatan}

Sarana peribadatan merupakan sarana kehidupan untuk mengisi kebutuhan rohani yang perlu disediakan di lingkungan perumahan yang direncanakan selain sesuai peraturan yang ditetapkan, juga sesuai dengan keputusan masyarakat yang bersangkutan. Oleh karena berbagai macam agama dan kepercayaan yang dianut oleh masyarakat penghuni yang bersangkutan, maka kepastian tentang jenis dan jumlah fasilitas peribadatan yang akandibangun baru dapat dipastikan setelah lingkungan perumahan dihuni selama beberapa waktu. Pendekatan perencanaan yang diatur adalah dengan memperkirakan populasi dan jenis agama serta kepercayaan dan kemudian merencanakan alokasi tanah dan lokasi bangunan peribadatan sesuai dengan tuntutan planologis dan religius.

Dasar penyediaan ini juga akan mempertimbangkan pendekatan desain keruangan unit-unit atau kelompok lingkungan yang ada. Hal ini dapat terkait dengan bentukan grup bangunan / blok yang nantinya lahir sesuai konteks lingkungannya. Penempatan penyediaan fasilitas ini akan mempertimbangkan jangkauan radius area layanan terkait dengan kebutuhan dasar sarana yang harus dipenuhi untuk melayani area tertentu.

Jenis sarana 
Jenis sarana peribadatan sangat tergantung pada kondisi setempat dengan memperhatikan struktur penduduk menurut agama yang dianut, dan tata cara atau pola masyarakat setempat dalam menjalankan ibadah agamanya

Adapun jenis sarana ibadah untuk agama Islam, direncanakan sebagai berikut; a) kelompok penduduk 250 jiwa, diperlukan musholla/langgar;

b)kelompok penduduk 2.500 jiwa, disediakan masjid;

c) kelompok penduduk 30.000 jiwa, disediakan masjid kelurahan; dan

d) kelompok penduduk 120.000 jiwa, disediakan masjid kecamatan. Untuk sarana ibadah agama lain, direncanakan sebagai berikut:

a) katolik mengikuti paroki;

b) hindu mengikuti adat; dan

c) budha dan kristen protestan mengikuti sistem kekerabatan atau hirarki lembaga. Kebutuhan ruang dan lahan

Untuk sarana ibadah agama Islam dan Kristen Protestan dan Katolik, kebutuhan ruang dihitung dengan dasar perencanaan 1,2 $\mathrm{m}$ 2/jemaah, termasuk ruang ibadah, ruang pelayanan dan sirkulasi pergerakan.

Untuk sarana ibadah agama Islam, luas lahan minimal direncanakan sebagai berikut:

a) musholla/langgar dengan luas lahan minimal $45 \mathrm{~m} 2$;

b) mesjid dengan luas lahan minimal $300 \mathrm{~m} 2$;

c) mesjid kelurahan dengan luas lahan minimal $1.800 \mathrm{~m} 2$;

d) mesjid kecamatan dengan luas lahan minimal $3.600 \mathrm{~m} 2$;

Untuk agama lain, kebutuhan ruang dan lahan disesuaikan dengan kebiasaan penganut agama setempat dalam melakukan ibadah agamanya. 
Tabel 13 Kebutuhan sarana peribadatan

\begin{tabular}{|c|c|c|c|c|c|c|c|}
\hline \multirow[b]{2}{*}{ No. } & \multirow{2}{*}{$\begin{array}{l}\text { Jenis } \\
\text { Sarana }\end{array}$} & \multirow{2}{*}{$\begin{array}{l}\text { Jumlah } \\
\text { Penduduk } \\
\text { pendukung } \\
\text { (jiwa) }\end{array}$} & \multicolumn{2}{|c|}{$\begin{array}{c}\begin{array}{c}\text { Kebutuhan Per Satuan } \\
\text { Sarana }\end{array} \\
\end{array}$} & \multirow{2}{*}{$\begin{array}{l}\text { Standard } \\
\left(\mathrm{m}^{2} / \text { jiwa }\right)\end{array}$} & \multicolumn{2}{|c|}{ Kriteria } \\
\hline & & & $\begin{array}{c}\text { Luas } \\
\text { Lantai Min. } \\
\left(\mathrm{m}^{2}\right)\end{array}$ & $\begin{array}{c}\text { Luas } \\
\text { Lahan Min. } \\
\left(\mathrm{m}^{2}\right)\end{array}$ & & $\begin{array}{c}\text { Radius } \\
\text { pencapaian }\end{array}$ & $\begin{array}{l}\text { Lokasi dan } \\
\text { Penyelesaian }\end{array}$ \\
\hline 1. & $\begin{array}{l}\text { Musholla/ } \\
\text { Langgar }\end{array}$ & 250 & 45 & $\begin{array}{r}100 \\
\text { bila } \\
\text { bangunan } \\
\text { tersendiri }\end{array}$ & 0,36 & $100 \mathrm{~m}^{\prime}$ & $\begin{array}{l}\text { Di tengah kelompok } \\
\text { tetangga. } \\
\text { Dapat merupakan } \\
\text { bagian dari } \\
\text { bangunan sarana } \\
\text { lain }\end{array}$ \\
\hline 2. & $\begin{array}{l}\text { Mesjid } \\
\text { Warga }\end{array}$ & 2.500 & 300 & 600 & 0,24 & $1.000 \mathrm{~m}^{\prime}$ & $\begin{array}{l}\text { Di tengah kelompok } \\
\text { tetangga tidak } \\
\text { menyeberang jalan } \\
\text { raya. } \\
\text { Dapat bergabung } \\
\text { dalam lokasi balai } \\
\text { warga. }\end{array}$ \\
\hline 3. & $\begin{array}{l}\text { Mesjid } \\
\text { Lingkungan } \\
\text { (Kelurahan) }\end{array}$ & 30.000 & 1.800 & 3.600 & 0,12 & & $\begin{array}{l}\text { Dapat dijangkau } \\
\text { dengan kendaraan } \\
\text { umum }\end{array}$ \\
\hline 4. & $\begin{array}{l}\text { Mesjid } \\
\text { Kecamatan }\end{array}$ & 120.000 & 3.600 & 5.400 & 0,03 & & $\begin{array}{l}\text { Berdekatan dengan } \\
\text { pusat lingkungan / } \\
\text { kelurahan. } \\
\text { Sebagian sarana } \\
\text { berlantai } 2, \mathrm{KDB} \\
40 \%\end{array}$ \\
\hline 5. & $\begin{array}{l}\text { Sarana } \\
\text { ibadah } \\
\text { agama lain }\end{array}$ & $\begin{array}{l}\text { Tergantung } \\
\text { sistem } \\
\text { kekerabatan / } \\
\text { hirarki } \\
\text { lembaga }\end{array}$ & $\begin{array}{l}\text { Tergantung } \\
\text { kebiasaan } \\
\text { setempat }\end{array}$ & $\begin{array}{l}\text { Tergantung } \\
\text { kebiasaan } \\
\text { setempat }\end{array}$ & - & - & - \\
\hline
\end{tabular}

CATATAN Acuan diambil dari Kota SNI 03-1733-1989, tentang Tata cara perencanaan kawasan perumahan kota.

\section{G. Sarana perdagangan dan niaga}

Sarana perdagangan dan niaga ini tidak selalu berdiri sendiri dan terpisah dengan bangunan sarana yang lain. Dasar penyediaan selain berdasarkan jumlah penduduk yang akan dilayaninya, juga mempertimbangkan pendekatan desain keruangan unit-unit atau kelompok lingkungan yang ada. Tentunya hal ini dapat terkait dengan bentukan grup bangunan / blok yang nantinya terbentuk sesuai konteks lingkungannya. Sedangkan penempatan penyediaan fasilitas ini akan mempertimbangkan jangkauan radius area layanan terkait dengan kebutuhan dasar sarana yang harus dipenuhi untuk melayani pada area tertentu.

\section{Jenis sarana}

Menurut skala pelayanan, penggolongan jenis sarana perdagangan dan niaga adalah:

a) toko/warung (skala pelayanan unit $\mathrm{RT} \approx 250$ penduduk), yang menjual barang-barang kebutuhan sehari-hari; 
b) pertokoan (skala pelayanan 6.000 penduduk), yang menjual barangbarang kebutuhan sehari-hari yang lebih lengkap dan pelayanan jasa seperti wartel, fotocopy, dan sebagainya;

c) pusat pertokoan dan atau pasar lingkungan (skala pelayanan unit kelurahan $\approx 30.000$ penduduk), yang menjual keperluan sehari-hari termasuk sayur, daging, ikan, buah- buahan, beras, tepung, bahan-bahan pakaian, pakaian, barang-barang kelontong, alat- alat pendidikan, alat-alat rumah tangga, serta pelayanan jasa seperti warnet, wartel dan sebagainya;

d) pusat perbelanjaan dan niaga (skala pelayanan unit kecamatan $\approx 120.000$ penduduk), yang selain menjual kebutuhan sehari-hari, pakaian, barang kelontong, elektronik, juga untuk pelayanan jasa perbengkelan, reparasi, unit-unit produksi yang tidak menimbulkan polusi, tempat hiburan serta kegiatan niaga lainnya seperti kantor-kantor,bank, industri kecil dan lainlain.

Kebutuhan ruang dan lahan

Kebutuhan ruang dan lahan untuk sarana ini akan berkaitan juga dengan daya dukung lingkungan dan jalan yang ada di sekitar bangunan sarana tersebut. Besaran kebutuhan ruang dan lahan menurut penggolongan jenis sarana perdagangan dan niaga adalah:

a) warung / took Luas lantai yang dibutuhkan $\pm 50 \mathrm{~m} 2$ termasuk gudang kecil.Apabila merupakan bangunan tersendiri (tidak bersatu dengan rumah tinggal), luas tanah yang dibutuhkan adalah $100 \mathrm{~m} 2$.

b) pertokoan (skala pelayanan untuk 6.000 penduduk) Luas lantai yang dibutuhkan $1.200 \mathrm{~m}$ 2. Sedangkan luas tanah yang dibutuhkan $3.000 \mathrm{~m} 2$.

Bangunan pertokoan ini harus dilengkapi dengan:

1) tempat parkir kendaraan umum yang dapat dipakai bersama kegiatan lain pada pusat lingkungan;

2) sarana-sarana lain yang erat kaitannya dengan kegiatan warga;

3) pos keamanan.

c) pusat pertokoan dan atau pasar lingkungan (skala pelayanan unit kelurahan $\approx 30.000$ penduduk) Luas tanah yang dibutuhkan: $10.000 \mathrm{~m} 2$. Bangunan pusat pertokoan / pasar lingkungan ini harus dilengkapi dengan: 1) tempat parkir umum, sudah termasuk kebutuhan luas tanah; 2) terminal kecil atau pangkalan untuk pemberhentian kendaraan;

3) pos keamanan; 
4) sistem pemadam kebakaran;

5) musholla/tempat ibadah.

d) pusat perbelanjaan dan niaga (skala pelayanan unit kelurahan $\approx 120.000$ penduduk) Luas tanah yang dibutuhkan adalah $36.000 \mathrm{~m} 2$. Bangunan pusat perbelanjaan harus dilengkapi:

1) tempat parkir umum, sudah termasuk kebutuhan luas tanah;

2) terminal atau pangkalan untuk pemberhentian kendaraan;

3) pos keamanan;

4) sistem pemadam kebakaran;

5) musholla/tempat ibadah.

Tabel 14 Jenis sarana perdagangan dan niaga

\begin{tabular}{|c|c|c|c|c|c|c|c|}
\hline \multirow[b]{2}{*}{ No. } & \multirow[b]{2}{*}{ Jenis Sarana } & \multirow{2}{*}{$\begin{array}{l}\text { Jumlah } \\
\text { Penduduk } \\
\text { pendukung } \\
\text { (jiwa) }\end{array}$} & \multicolumn{2}{|c|}{$\begin{array}{l}\text { Kebutuhan Per } \\
\text { Satuan Sarana }\end{array}$} & \multirow[b]{2}{*}{$\begin{array}{l}\text { Standard } \\
\left(\mathrm{m}^{2} / \mathrm{jiwa}\right)\end{array}$} & \multicolumn{2}{|c|}{ Kriteria } \\
\hline & & & $\begin{array}{l}\text { Luas } \\
\text { Lantai } \\
\text { Min. } \\
\left(\mathrm{m}^{2}\right)\end{array}$ & $\begin{array}{l}\text { Luas } \\
\text { Lahan } \\
\text { Min. } \\
\left(\mathrm{m}^{2}\right)\end{array}$ & & $\begin{array}{c}\text { Radius } \\
\text { pencapaian }\end{array}$ & $\begin{array}{l}\text { Lokasi dan } \\
\text { Penyelesaian }\end{array}$ \\
\hline 1. & $\begin{array}{l}\text { Toko I } \\
\text { Warung }\end{array}$ & 250 & $\begin{array}{r}50 \\
\text { (termasuk } \\
\text { gudang) }\end{array}$ & $\begin{array}{r}100 \\
\text { (bila } \\
\text { berdiri } \\
\text { sendiri) }\end{array}$ & 0,4 & $300 \mathrm{~m}^{\prime}$ & $\begin{array}{l}\text { Di tengah } \\
\text { kelompok tetangga. } \\
\text { Dapat merupakan } \\
\text { bagian dari sarana } \\
\text { lain }\end{array}$ \\
\hline 2. & Pertokoan & 6.000 & 1.200 & 3.000 & 0,5 & $2.000 \mathrm{~m}^{\prime}$ & $\begin{array}{l}\text { Di pusat kegiatan } \\
\text { sub lingkungan. } \\
\text { KDB } 40 \% \text { Dapat } \\
\text { berbentuk P\&D }\end{array}$ \\
\hline 3. & $\begin{array}{l}\text { Pusat } \\
\text { Pertokoan + } \\
\text { Pasar } \\
\text { Lingkungan }\end{array}$ & 30.000 & 13.500 & 10.000 & 0,33 & & $\begin{array}{l}\text { Dapat dijangkau } \\
\text { dengan kendaraan } \\
\text { umum }\end{array}$ \\
\hline 4. & $\begin{array}{l}\text { Pusat } \\
\text { Perbelanjaan } \\
\text { dan Niaga } \\
\text { (toko + pasar } \\
\text { + bank + } \\
\text { kantor) }\end{array}$ & 120.000 & 36.000 & 36.000 & 0,3 & & $\begin{array}{l}\text { Terletak di jalan } \\
\text { utama. } \\
\text { Termasuk sarana } \\
\text { parkir sesuai } \\
\text { ketentuan } \\
\text { setempat }\end{array}$ \\
\hline
\end{tabular}

CATATAN Acuan diambil dari SNI 03-1733-1989, Tata cara perencanaan kawasan perumahan kota 


\section{BAB III}

\section{PEMBAHASAN}

A. Peta Wilayah Mungkajang

PETA KECAMATAN MUNGKAJANG

KOTA PALOPO

PROVINSI SULAWESI SELATAN

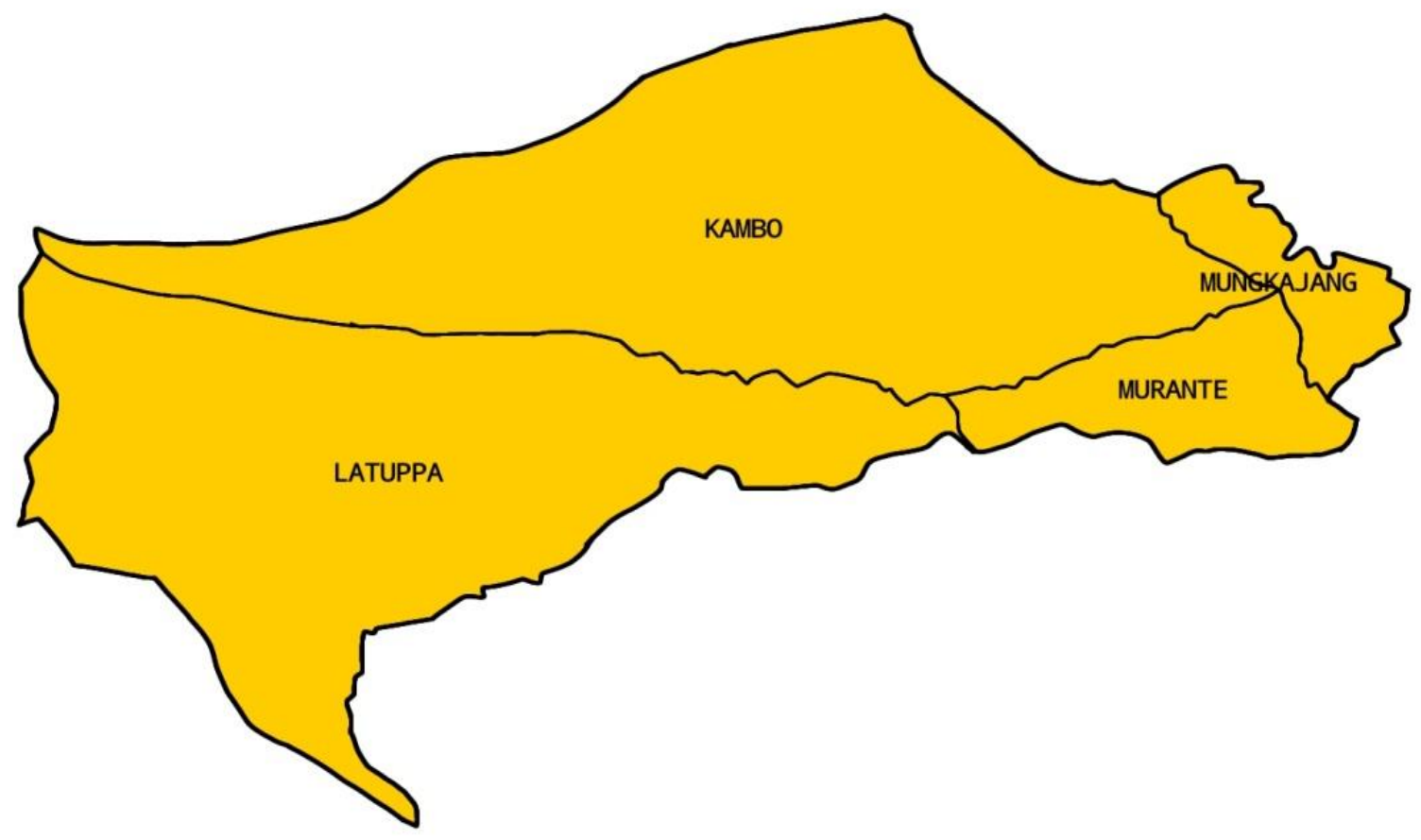


B. Jumlah Penduduk 5 Tahun Terahkir BesertaProyeksinya

\begin{tabular}{|c|c|c|c|c|c|}
\hline NO & Kecamatam & $\begin{array}{c}\text { Tahun } \\
2018\end{array}$ & Tahun 2019 & Rasio(R) & TAHUN 2024 \\
\hline 1 & Mungkajang & 3,152 & 3,221 & 0.022 & 3,574 \\
2 & Murante & 2,328 & 2,380 & 0.022 & 2,646 \\
3 & Latuppa & 1,564 & 1,598 & 0.022 & 1,772 \\
4 & Kambo & 1,058 & 1,080 & 0.021 & 1,192 \\
\hline
\end{tabular}

\begin{tabular}{|c|c|c|c|c|c|}
\hline NO & Kecamatam & $\begin{array}{c}\text { Tahun } \\
2018\end{array}$ & $\begin{array}{c}\text { Tahun } \\
2019\end{array}$ & Rasio(R) & TAHUN 2029 \\
\hline & & & & & \\
1 & Mungkajang & 3,152 & 3,221 & 0.022 & 3,926 \\
2 & Murante & 2,328 & 2,380 & 0.022 & 2,912 \\
3 & Latuppa & 1,564 & 1,598 & 0.022 & 1,945 \\
4 & Kambo & 1,058 & 1,080 & 0.021 & 1,305 \\
\hline
\end{tabular}

\begin{tabular}{|c|c|c|c|c|c|}
\hline NO & Kecamatam & $\begin{array}{c}\text { Tahun } \\
2018\end{array}$ & $\begin{array}{c}\text { Tahun } \\
2019\end{array}$ & Rasio(R) & TAHUN 2034 \\
\hline 1 & Mungkajang & 3,152 & 3,221 & 0.022 & 4,279 \\
2 & Murante & 2,328 & 2,380 & 0.022 & 3,177 \\
3 & Latuppa & 1,564 & 1,598 & 0.022 & 2,119 \\
4 & Kambo & 1,058 & 1,080 & 0.021 & 1,417 \\
\hline
\end{tabular}

\begin{tabular}{|c|c|c|c|c|c|}
\hline NO & \multirow{2}{*}{ Kecamatam } & $\begin{array}{c}\text { Tahun } \\
2018\end{array}$ & $\begin{array}{c}\text { Tahun } \\
2019\end{array}$ & Rasio(R) & $\begin{array}{c}\text { TAHUN } \\
2039\end{array}$ \\
\hline 1 & Mungkajang & 3,152 & 3,221 & 0.022 & 4,631 \\
2 & Murante & 2,328 & 2,380 & 0.022 & 3,443 \\
3 & Latuppa & 1,564 & 1,598 & 0.022 & 2,293 \\
4 & Kambo & 1,058 & 1,080 & 0.021 & 1,529 \\
\hline
\end{tabular}


C. Kebutuhan Sarana Dan Prasarana Tahun 2024,2029,2034,2039

a Sarana Pendidikan

Tahun 2024

\begin{tabular}{|l|l|l|l|l|l|l|}
\hline NO & \multicolumn{1}{|c|}{$\begin{array}{c}\text { Sarana } \\
\text { Pendidikan }\end{array}$} & $\begin{array}{c}\text { Jumlah } \\
\text { Penduduk } \\
\text { Tahun } \\
2024\end{array}$ & $\begin{array}{c}\text { Jumlah } \\
\text { Sarana } \\
\text { Pendidikan }\end{array}$ & $\begin{array}{c}\text { Jumlah } \\
\text { Penduduk } \\
\text { Pendukung }\end{array}$ & $\begin{array}{c}\text { Kebutuhan } \\
\text { Berdasarkan } \\
\text { Sarana } \\
\text { SNI }\end{array}$ & Penambahan \\
\hline 1 & \multirow{2}{*}{9,184} & 4 & 1,250 & 7 & 3 \\
\hline 2 & SD/MI & 5 & 1,600 & 6 & 1 \\
\hline 3 & SMP/MTS & & 1 & 4,800 & 2 & 1 \\
\hline 4 & SMU/SMK & & 1 & 4,800 & 2 & 1 \\
\hline
\end{tabular}

Tahun 2029

\begin{tabular}{|c|c|c|c|c|c|c|}
\hline $\mathrm{NO}$ & $\begin{array}{c}\text { Sarana } \\
\text { Pendidikan }\end{array}$ & $\begin{array}{c}\text { Jumlah } \\
\text { Penduduk } \\
\text { Tahun } \\
2029\end{array}$ & $\begin{array}{c}\text { Jumlah } \\
\text { Sarana } \\
\text { Pendidikan }\end{array}$ & $\begin{array}{c}\text { Jumlah } \\
\text { Penduduk } \\
\text { Pendukung }\end{array}$ & $\begin{array}{c}\text { Kebutuhan } \\
\text { Berdasarkan } \\
\text { Sarana } \\
\text { SNI }\end{array}$ & Penambahan \\
\hline 1 & TK & \multirow{4}{*}{10,124} & 4 & 1,250 & 8 & 4 \\
\hline 2 & SD/MI & & 5 & 1,600 & 6 & 1 \\
\hline 3 & SMP/MTS & & 1 & 4,800 & 2 & 1 \\
\hline 4 & SMU/SMK & & 1 & 4,800 & 2 & 1 \\
\hline
\end{tabular}


Tahun 2034

\begin{tabular}{|l|l|l|l|l|l|l|}
\hline NO & \multicolumn{1}{|c|}{$\begin{array}{c}\text { Sarana } \\
\text { Pendidikan }\end{array}$} & $\begin{array}{c}\text { Jumlah } \\
\text { Penduduk } \\
\text { Tahun } \\
2034\end{array}$ & $\begin{array}{c}\text { Jumlah } \\
\text { Sarana } \\
\text { Pendidikan }\end{array}$ & $\begin{array}{c}\text { Jumlah } \\
\text { Penduduk } \\
\text { Pendukung }\end{array}$ & $\begin{array}{c}\text { Kebutuhan } \\
\text { Berdasarkan } \\
\text { Sarana } \\
\text { SNI }\end{array}$ & Penambahan \\
\cline { 1 - 4 } 1 & \multirow{2}{*}{10,992} & TK & 4 & 1,250 & 9 & 5 \\
\hline 2 & SD/MI & 1 & 1,600 & 7 & 2 \\
\hline 3 & SMP/MTS & & 4,800 & 2 & 1 \\
\hline 4 & SMU/SMK & & 1 & 4,800 & 2 & 1 \\
\hline
\end{tabular}

Tahun 2039

\begin{tabular}{|c|c|c|c|c|c|c|}
\hline $\mathrm{NO}$ & $\begin{array}{c}\text { Sarana } \\
\text { Pendidikan }\end{array}$ & $\begin{array}{c}\text { Jumlah } \\
\text { Penduduk } \\
\text { Tahun } \\
2039\end{array}$ & $\begin{array}{c}\text { Jumlah } \\
\text { Sarana } \\
\text { Pendidikan }\end{array}$ & $\begin{array}{c}\text { Jumlah } \\
\text { Penduduk } \\
\text { Pendukung }\end{array}$ & $\begin{array}{c}\text { Kebutuhan } \\
\text { Berdasarkan } \\
\text { Sarana } \\
\text { SNI }\end{array}$ & Penambahan \\
\hline 1 & TK & \multirow{4}{*}{11,896} & 4 & 1,250 & 10 & \\
\hline 2 & SD/MI & & 5 & 1,600 & 7 & \\
\hline 3 & SMP/MTS & & 1 & 4,800 & 2 & \\
\hline 4 & SMU/SMK & & 1 & 4,800 & 2 & \\
\hline
\end{tabular}


b Sarana Kesehatan

Tahun 2024

\begin{tabular}{|c|c|c|c|c|c|c|}
\hline NO & $\begin{array}{c}\text { Sarana } \\
\text { Kesehatam }\end{array}$ & $\begin{array}{c}\text { Jumlah } \\
\text { Penduduk } \\
\text { Tahun } \\
2024\end{array}$ & $\begin{array}{c}\text { Jumlah } \\
\text { Sarana } \\
\text { Kesehatan }\end{array}$ & $\begin{array}{c}\text { Jumlah } \\
\text { Penduduk } \\
\text { Pendukung }\end{array}$ & $\begin{array}{c}\text { Kebutuhan } \\
\text { Berdasarkan } \\
\text { Sarana } \\
\text { SNI }\end{array}$ & Penambahan \\
\hline 1 & Posyandu & \multirow{7}{*}{9,184} & 14 & 1,250 & 7 & -7 \\
\hline 2 & $\begin{array}{l}\text { Balai } \\
\text { Pengobatan } \\
\text { Warga }\end{array}$ & & 0 & 2,500 & 4 & 4 \\
\hline 3 & $\begin{array}{l}\text { BKIA/Klinik } \\
\text { Bersalin }\end{array}$ & & 0 & 4,800 & 2 & 2 \\
\hline 4 & $\begin{array}{l}\text { Puskesmas } \\
\text { Pembantu } \\
\text { Dan Balai } \\
\text { Pengobatan } \\
\text { Lingkungan }\end{array}$ & & 6 & 4,800 & 2 & -4 \\
\hline 5 & $\begin{array}{l}\text { Puskesmas } \\
\text { Dan Balai } \\
\text { Pengobatan } \\
\text { Limgkungan }\end{array}$ & & 1 & 120,000 & 0 & -1 \\
\hline 6 & $\begin{array}{l}\text { Tempat } \\
\text { Praktek } \\
\text { Dokter }\end{array}$ & & 5 & 5,000 & 2 & -3 \\
\hline 7 & Apotik & & 1 & 30,000 & 0 & -1 \\
\hline
\end{tabular}


Tahun 2029

\begin{tabular}{|c|c|c|c|c|c|c|}
\hline NO & $\begin{array}{c}\text { Sarana } \\
\text { Kesehatam }\end{array}$ & $\begin{array}{c}\text { Jumlah } \\
\text { Penduduk } \\
\text { Tahun } \\
2029\end{array}$ & $\begin{array}{c}\text { Jumlah } \\
\text { Sarana } \\
\text { Kesehatan }\end{array}$ & $\begin{array}{c}\text { Jumlah } \\
\text { Penduduk } \\
\text { Pendukung }\end{array}$ & $\begin{array}{c}\text { Kebutuhan } \\
\text { Berdasarkan } \\
\text { Sarana } \\
\text { SNI }\end{array}$ & Penambahan \\
\hline 1 & Posyandu & \multirow{7}{*}{10,124} & 14 & 1,250 & 8 & -6 \\
\hline 2 & $\begin{array}{l}\text { Balai } \\
\text { Pengobatan } \\
\text { Warga }\end{array}$ & & 0 & 2,500 & 4 & 4 \\
\hline 3 & $\begin{array}{l}\text { BKIA/Klinik } \\
\text { Bersalin }\end{array}$ & & 0 & 4,800 & 2 & 2 \\
\hline 4 & $\begin{array}{l}\text { Puskesmas } \\
\text { Pembantu } \\
\text { Dan Balai } \\
\text { Pengobatan } \\
\text { Lingkungan }\end{array}$ & & 6 & 4,800 & 2 & -4 \\
\hline 5 & $\begin{array}{l}\text { Puskesmas } \\
\text { Dan Balai } \\
\text { Pengobatan } \\
\text { Limgkungan }\end{array}$ & & 1 & 120,000 & 0 & -1 \\
\hline 6 & $\begin{array}{l}\text { Tempat } \\
\text { Praktek } \\
\text { Dokter }\end{array}$ & & 5 & 5,000 & 2 & -3 \\
\hline 7 & Apotik & & 1 & 30,000 & 0 & -1 \\
\hline
\end{tabular}


Tahun 2034

\begin{tabular}{|c|c|c|c|c|c|c|}
\hline NO & $\begin{array}{c}\text { Sarana } \\
\text { Kesehatam }\end{array}$ & $\begin{array}{c}\text { Jumlah } \\
\text { Penduduk } \\
\text { Tahun } \\
2034\end{array}$ & $\begin{array}{c}\text { Jumlah } \\
\text { Sarana } \\
\text { Kesehatan }\end{array}$ & $\begin{array}{c}\text { Jumlah } \\
\text { Penduduk } \\
\text { Pendukung }\end{array}$ & $\begin{array}{c}\text { Kebutuhan } \\
\text { Berdasarkan } \\
\text { Sarana } \\
\text { SNI }\end{array}$ & Penambahan \\
\hline 1 & Posyandu & \multirow{7}{*}{10,992} & 14 & 1,250 & 9 & -5 \\
\hline 2 & $\begin{array}{l}\text { Balai } \\
\text { Pengobatan } \\
\text { Warga }\end{array}$ & & 0 & 2,500 & 4 & 4 \\
\hline 3 & $\begin{array}{l}\text { BKIA/Klinik } \\
\text { Bersalin }\end{array}$ & & 0 & 4,800 & 2 & 2 \\
\hline 4 & $\begin{array}{l}\text { Puskesmas } \\
\text { Pembantu } \\
\text { Dan Balai } \\
\text { Pengobatan } \\
\text { Lingkungan }\end{array}$ & & 6 & 4,800 & 2 & -4 \\
\hline 5 & $\begin{array}{l}\text { Puskesmas } \\
\text { Dan Balai } \\
\text { Pengobatan } \\
\text { Limgkungan }\end{array}$ & & 1 & 120,000 & 0 & -1 \\
\hline 6 & $\begin{array}{l}\text { Tempat } \\
\text { Praktek } \\
\text { Dokter }\end{array}$ & & 5 & 5,000 & 2 & -3 \\
\hline 7 & Apotik & & 1 & 30,000 & 0 & -1 \\
\hline
\end{tabular}


Tahun 2039

\begin{tabular}{|c|c|c|c|c|c|c|}
\hline NO & $\begin{array}{c}\text { Sarana } \\
\text { Kesehatam }\end{array}$ & $\begin{array}{c}\text { Jumlah } \\
\text { Penduduk } \\
\text { Tahun } \\
2039\end{array}$ & $\begin{array}{c}\text { Jumlah } \\
\text { Sarana } \\
\text { Kesehatan }\end{array}$ & $\begin{array}{c}\text { Jumlah } \\
\text { Penduduk } \\
\text { Pendukung }\end{array}$ & $\begin{array}{c}\text { Kebutuhan } \\
\text { Berdasarkan } \\
\text { Sarana } \\
\text { SNI }\end{array}$ & Penambahan \\
\hline 1 & Posyandu & \multirow{7}{*}{11,896} & 14 & 1,250 & 9 & -5 \\
\hline 2 & $\begin{array}{l}\text { Balai } \\
\text { Pengobatan } \\
\text { Warga }\end{array}$ & & 0 & 2,500 & 4 & 4 \\
\hline 3 & $\begin{array}{l}\text { BKIA/Klinik } \\
\text { Bersalin }\end{array}$ & & 0 & 4,800 & 2 & 2 \\
\hline 4 & $\begin{array}{l}\text { Puskesmas } \\
\text { Pembantu } \\
\text { Dan Balai } \\
\text { Pengobatan } \\
\text { Lingkungan }\end{array}$ & & 6 & 4,800 & 2 & -4 \\
\hline 5 & $\begin{array}{l}\text { Puskesmas } \\
\text { Dan Balai } \\
\text { Pengobatan } \\
\text { Limgkungan }\end{array}$ & & 1 & 120,000 & 0 & -1 \\
\hline 6 & $\begin{array}{l}\text { Tempat } \\
\text { Praktek } \\
\text { Dokter }\end{array}$ & & 5 & 5,000 & 2 & -3 \\
\hline 7 & Apotik & & 1 & 30,000 & 0 & -1 \\
\hline
\end{tabular}


c Sarana Perdagangan Dan Niaga

Tahun 2024

\begin{tabular}{|c|c|c|c|c|c|c|}
\hline $\mathrm{NO}$ & $\begin{array}{c}\text { Sarana } \\
\text { Perdagangan }\end{array}$ & $\begin{array}{c}\text { Jumlah } \\
\text { Penduduk } \\
\text { Tahun } \\
2024\end{array}$ & $\begin{array}{c}\text { Jumlah } \\
\text { Sarana } \\
\text { Perdagangan }\end{array}$ & $\begin{array}{c}\text { Jumlah } \\
\text { Penduduk } \\
\text { Pendukung }\end{array}$ & $\begin{array}{c}\text { Kebutuhan } \\
\text { Berdasarkan } \\
\text { Sarana } \\
\text { SNI }\end{array}$ & Penambahan \\
\hline 1 & Toko/Warung & \multirow{4}{*}{9,184} & 110 & 250 & 37 & -73 \\
\hline 2 & Pertokoan & & 1 & 6,000 & 1 & 0 \\
\hline 3 & $\begin{array}{l}\text { Pusat } \\
\text { Pertokoan } \\
\text { /Pasar } \\
\text { Lingkungan }\end{array}$ & & 1 & 30,000 & 0 & -1 \\
\hline 4 & $\begin{array}{l}\text { Pusat Belanja } \\
\text { Niaga }\end{array}$ & & 0 & 120,000 & 0 & 0 \\
\hline
\end{tabular}

Tahun 2029

\begin{tabular}{|c|c|c|c|c|c|c|}
\hline $\mathrm{NO}$ & $\begin{array}{c}\text { Sarana } \\
\text { Perdagangan }\end{array}$ & $\begin{array}{l}\text { Jumlah } \\
\text { Penduduk } \\
\text { Tahun } \\
2029\end{array}$ & $\begin{array}{c}\text { Jumlah } \\
\text { Sarana } \\
\text { Perdagangan }\end{array}$ & $\begin{array}{c}\text { Jumlah } \\
\text { Penduduk } \\
\text { Pendukung }\end{array}$ & $\begin{array}{c}\text { Kebutuhan } \\
\text { Berdasarkan } \\
\text { Sarana } \\
\text { SNI }\end{array}$ & Penambahan \\
\hline 1 & Toko/Warung & \multirow{4}{*}{10,124} & 110 & 250 & 40 & -70 \\
\hline 2 & Pertokoan & & 1 & 6,000 & 2 & 1 \\
\hline 3 & $\begin{array}{l}\text { Pusat } \\
\text { Pertokoan } \\
\text { /Pasar } \\
\text { Lingkungan }\end{array}$ & & 1 & 30,000 & 0 & -1 \\
\hline 4 & $\begin{array}{l}\text { Pusat Belanja } \\
\text { Niaga }\end{array}$ & & 0 & 120,000 & 0 & 0 \\
\hline
\end{tabular}


Tahun 2034

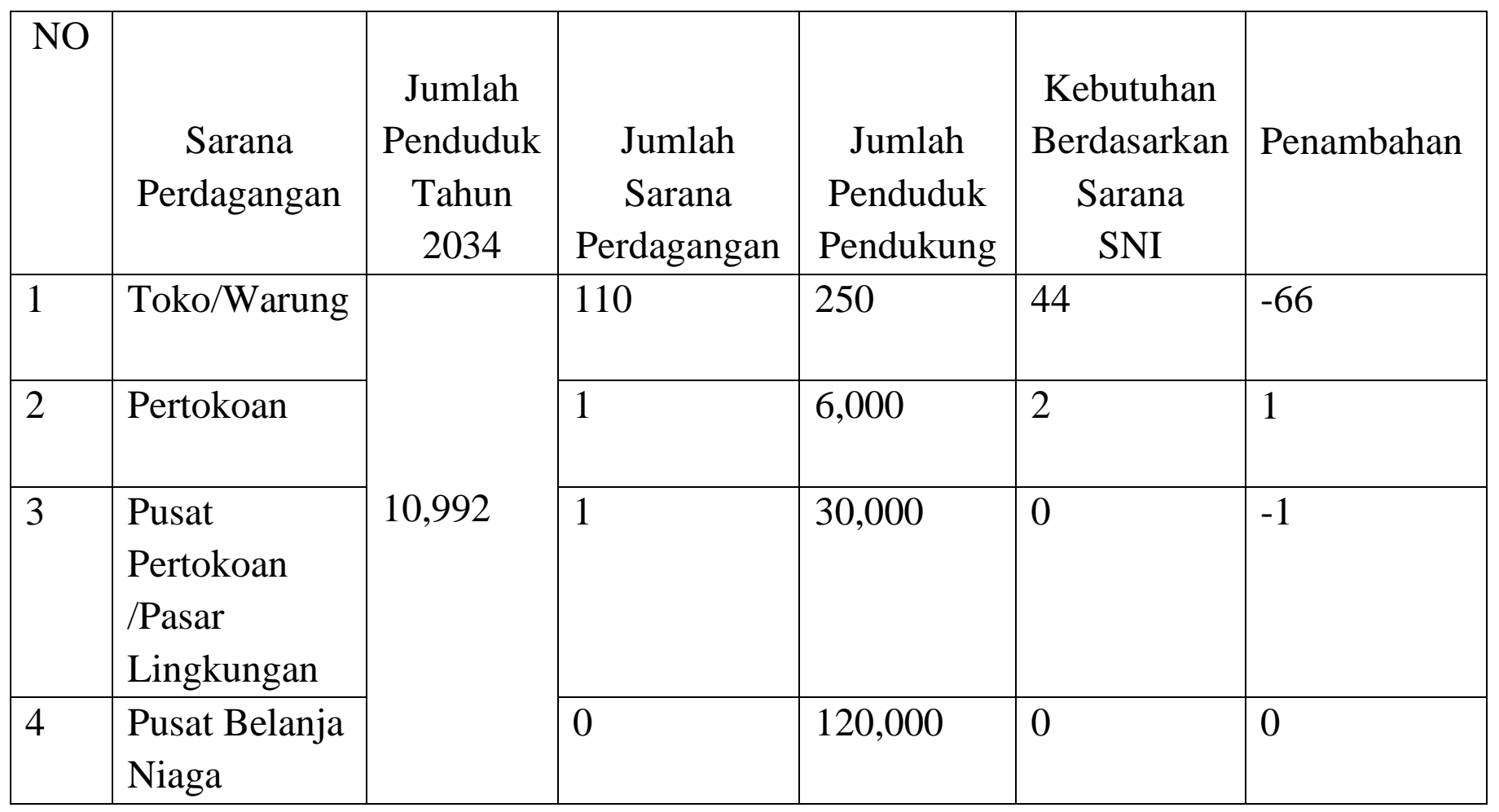

Tahun 2039

\begin{tabular}{|c|c|c|c|c|c|c|}
\hline NO & $\begin{array}{c}\text { Sarana } \\
\text { Perdagangan }\end{array}$ & $\begin{array}{c}\text { Jumlah } \\
\text { Penduduk } \\
\text { Tahun } \\
2039\end{array}$ & $\begin{array}{c}\text { Jumlah } \\
\text { Sarana } \\
\text { Perdagangan }\end{array}$ & $\begin{array}{c}\text { Jumlah } \\
\text { Penduduk } \\
\text { Pendukung }\end{array}$ & $\begin{array}{c}\text { Kebutuhan } \\
\text { Berdasarkan } \\
\text { Sarana } \\
\text { SNI }\end{array}$ & Penambahan \\
\hline 1 & Toko/Warung & \multirow{4}{*}{11,896} & 110 & 250 & 47 & -63 \\
\hline 2 & Pertokoan & & 1 & 6,000 & 2 & 1 \\
\hline 3 & $\begin{array}{l}\text { Pusat } \\
\text { Pertokoan } \\
\text { /Pasar } \\
\text { Lingkungan }\end{array}$ & & 1 & 30,000 & 0 & -1 \\
\hline 4 & $\begin{array}{l}\text { Pusat Belanja } \\
\text { Niaga }\end{array}$ & & 0 & 120,000 & 0 & 0 \\
\hline
\end{tabular}




\section{BAB IV \\ PENUTUP}

Kesimpulan

Proyeksi penduduk di perlukan pemerintah untuk memproyeksikan penduduk yang sesuai dengan tanggung jawabnya untuk memperbaiki kondisi sosial ekonomi dari rakyat melalui pembangunan yang terencana.

Proyeksi penduduk dapat di gunakan untuk,perencanaan yang tujuan nya untuk menyediakan jasa sebagai respon terhadap penduduk yang sudah di proyeksi kan,perencanaan yang tujuannya untuk merubah trend penduduk menuju ke perkembangan demografi sosial dan Ekonomi.

Untuk memproyeksi kan jumlah penduduk pada waktu yang akan datang dalam jangka waktu yang relatif pendek dapat di lakukan baik dengan menggunakan metode matematik maupun metode komponen karena hasil secara total hampir tak ada perbedaan.

Sarana

Ada pun yang menjadi saran dari isi pembahasan makalah ini adalah :

1. Di harapkan kepada Pemerintah untuk selalu teliti dan aktif dalam memproyeksikan proyeksi penduduk,demi memperbaiki kondisi sosial Ekonomi masyarakat.

2. Di harapkan kepada Pemerintah untuk melakukan sensus penduduk sesuai dengan ketentuan yang telah di bentuk agar dapat memenuhi permintaan secara efesien dalam keperluan suatu Negara oleh pemerintah. 


\section{DAFTAR PUSTAKA}

Fisu, A. A., \& Didiharyono, D. (2020, April). Economic \& Financial Feasibility Analysis of Tarakan Fishery Industrial Estate Masterplan. In IOP Conference Series: Earth and Environmental Science (Vol. 469, No. 1, p. 012002). IOP Publishing.

Fisu, A. A., \& Marzaman, L. U. (2018). Pemetaan Partisipatif Kampung Pesisir Kelurahan Tallo Kota Makassar. To Maega: Jurnal Pengabdian Masyarakat, 1(1), 22-28.

NI 03-1733-2004

https://soppengkab.bps.go.id/publication/download.html?nrbvfeve=ZDFiNT

ExNTYxNGVhYmE3NjI0MTE5MmY1\&xzmn=aHR0cHM6Ly9zb3BwZW

5na2FiLmJwcy5nby5pZC9wdWJsaWNhdGlvbi8yMDIxLzA5LzI0L2QxYj

UxMTU2MTRIYWJhNzYyNDExOTJmNS9rZWNhbWF0YW4tbWFyaW8t

cml3YXdvLWRhbGFtLWFuZ2thLTIwMjEuaHRtbA\%3D\%3D\&twoadfnoa

rfeauf=MjAyMi0wMS0xNiAxMTo1MToyOQ\%3D\%3D

https://prasaranadansaranabesusutengah.blogspot.com/2016/06/prasarana- dansarana-wilayah-kota

https://adoc.pub/bab-i-pendahuluan-suatu-daerah-pertumbuhan-ekonomi-yangberk.html

http://repository.unpas.ac.id/32601/2/BAB\%20II.pdf

http://nawasis.org/portal/download/digilib/369-SNI-2004_1733_03.pdf

https://luwukab.bps.go.id/publication/2021/09/24/79da5557c2ef938dc747c1e6/kec amatan-belopa-dalam-angka-2021.html 